Autonomic dysfunction is a long term complication of treatment with cisplatin, vinblastine, and bleomycin and may explain the impotence that occurs in some patients. Presumably these young men are at risk during anaesthesia as cardiorespiratory arrests have occurred in patients with similar dysfunction.

1 McLeod JG, Tuck RR. Disorders of the autonomic nervous system: part 1 . Pathophysiology and clinical features. Ann Neurol 1987;21:419-30.
2 Ewing DJ, Clarke BF. Autonomic neuropathy: its diagnosis and prognosis. Clinical Endocrinology and Metabolism 1986;15:855-88.

3 Hansen SW, Helweg-Larsen S, Trojaborg W. Long-term neurotoxicity in patients treated with cisplatin, vinblastine, and bleomycin for metastatic patients treated with cisplatin, vinblastine,

4 Page MMcB, Watkins PJ. Cardiorespiratory arrest and diabetic autonomic neuropathy. Lancet 1978 ;i:14-6.

5 Samuels BL, Vogelzang NJ, Kennedy BJ. Severe vascular toxicity associated with vinblastine, bleomycin, and cisplatin chemotherapy. Cancer Chemother Pharmacol 1987;19:253-6.

(Accepted 9 November 1989)

\section{Association between living conditions in childhood and myocardial infarction}

\author{
Henrik Hasle
}

\begin{abstract}
Institute of Community
Health, Department of

Social Medicine,

University of Odense,

5000 Odense C, Denmark

Henrik Hasle, MD, research
\end{abstract}

fellow

Br Med J 1990;300:512-3 semiskilled workers.
Several studies have reported an association between cardiovascular diseases in adulthood and poor living conditions in childhood. ${ }^{12}$ I studied the association between living conditions in childhood and myocardial infarction in a well defined group of male unskilled and

\section{Subjects, methods, and results}

I conducted a nested case-control study based on information obtained in a case-control study designed to elucidate the factors giving rise to disability pensions for unskilled and semiskilled workers. ${ }^{3}$ Each consecutive male member of the Danish general workers' union who was granted a disability pension (pensioner) between 1 January 1984 and 1 March 1986 was included in the study. For each pensioner three union members matched for age and sex were recruited as controls. A self administered postal questionnaire was returned by $2602(73 \cdot 3 \%)$ of the study population ( $75 \cdot 2 \%$ of the pensioners and $72 \cdot 6 \%$ of the controls). Only subjects who had been union members for over 10 years and were aged 50-67 were studied - that is, 448 pensioners and 1225 controls. My study was concerned only with answers to the question "Have you ever had a myocardial infarction?" and to questions about living conditions in childhood.

Altogether 154 of the study population had had a myocardial infarction (88 pensioners and 66 controls). No significant difference in the age distribution of those who had and had not had a myocardial infarction was observed (mean age $58 \cdot 1$ and 57.9 respectively). The table shows the results obtained from the questions on living conditions in childhood. Odds ratios and $95 \%$ confidence intervals were calculated for each question regarding the most common answer among the men who had had a myocardial infarction. No significant differences were observed in the study group overall, but broken homes and urban residence were significantly associated with myocardial infarction in the control group.

No differences were observed in essential indications of poverty such as father's occupation, long term unemployment, and economic problems. Although not significant, the odds ratio for myocardial infarction among men with a short education was notably increased $(1 \cdot 95)$.

\section{Comment}

The study relied on a self reported history of myocardial infarction, which seems justified because heart disease is one of the chronic illnesses for which self reporting is fairly accurate. The study was based on questionnaires received from men who had survived a myocardial infarction. Such survivors may have different backgrounds from those of people who die, although it seems unlikely that living conditions in childhood influence the chance of survival.

The results could be biased by the high number of pensioners in the study. Separate analyses of the pensioners and controls did not show any systematic differences. A previous case-control study showed no association between living conditions in childhood and receipt of a disability pension. ${ }^{3}$

The study population was strikingly homogeneous in terms of education: $89 \cdot 7 \%$ had received seven years' education or less. It is difficult to find significant associations in such a homogeneous group, although there was a fairly strong tendency towards fewer cases of myocardial infarction among those with more than seven years' education.

The results are inconsistent with previous population based studies. ${ }^{12}$ Finding unfavourable living conditions in childhood in an area with a high mortality from cardiovascular diseases does not necessarity imply a causal relation. The highest infant mortality is found in poor areas that have remained poor throughout the century, ${ }^{4}$ and the incidence of cardiovascular diseases is highest among the lowest social class. ${ }^{5}$ The association of myocardial infarction with childhood conditions ${ }^{12}$ could be explained by confounding as low social class is associated with infant mortality, poverty in childhood, and cardiovascular diseases.

Living conditions in childhood may influence a person's career and lifestyle in adulthood and so be an

Living conditions experienced in childhood by men who had had myocardial infarction

\begin{tabular}{|c|c|c|c|c|c|c|c|c|c|}
\hline & \multicolumn{3}{|c|}{$\begin{array}{l}\text { Men who were receiving } \\
\text { disability pension } \\
(\mathrm{n}=88)\end{array}$} & \multicolumn{3}{|c|}{$\begin{array}{l}\text { Men who were not receiving } \\
\text { disability pension } \\
(\mathrm{n}=66)\end{array}$} & \multicolumn{3}{|c|}{$\begin{array}{l}\text { Entire study group } \\
\qquad(n=154)\end{array}$} \\
\hline & No & $\begin{array}{l}\text { Odds } \\
\text { ratio }\end{array}$ & $\begin{array}{l}\text { 95\% Confidence } \\
\text { interval }\end{array}$ & No & $\begin{array}{l}\text { Odds } \\
\text { ratio }\end{array}$ & $\begin{array}{l}\text { 95\% Confidence } \\
\text { interval }\end{array}$ & No & $\begin{array}{l}\text { Odds } \\
\text { ratio }\end{array}$ & $\begin{array}{l}95 \% \text { Confidence } \\
\text { interval }\end{array}$ \\
\hline Father was an unskilled worker & 37 & $1 \cdot 24$ & 0.77 to 1.99 & 27 & $1 \cdot 07$ & 0.65 to 1.77 & 64 & $1 \cdot 13$ & 0.80 to 1.58 \\
\hline Did not grow up with both parents & 12 & 1.05 & 0.53 to 2.08 & 16. & 1.94 & 1.09 to 3.46 & 28 & $1 \cdot 38$ & 0.89 to $2 \cdot 12$ \\
\hline Father was unemployed for a long period & 15 & 0.95 & 0.51 to 1.76 & 16 & 1.27 & 0.71 to 2.27 & 31 & 1.04 & 0.69 to 1.57 \\
\hline Parents were sick & 26 & 1.54 & 0.92 to 2.59 & 14 & $0 \cdot 90$ & 0.49 to 1.64 & 40 & $1 \cdot 19$ & 0.82 to 1.74 \\
\hline Parents received disability pension & 22 & $1 \cdot 41$ & 0.81 to 2.43 & 10 & 0.81 & 0.32 to 2.04 & 32 & $1 \cdot 22$ & 0.81 to 1.84 \\
\hline Economic problems & 39 & $1 \cdot 30$ & 0.81 to 2.07 & 28 & 1.08 & 0.65 to 1.78 & 67 & $1 \cdot 16$ & 0.83 to 1.62 \\
\hline Urban residence & 27 & 1.05 & 0.63 to 1.74 & 27 & 1.84 & 1.11 to 3.03 & 54 & $1 \cdot 39$ & 0.98 to 1.98 \\
\hline$\leqslant 7$ Years of schooling & 83 & $2 \cdot 13$ & 0.83 to 5.46 & 62 & 1.84 & 0.67 to 5.07 & 145 & 1.95 & 0.99 to 3.85 \\
\hline
\end{tabular}


indirect risk factor for cardiovascular diseases. This study provides no support, however, for the hypothesis that poverty in childhood itself is causally related to myocardial infarction.

1 Barker DJP, Osmond C. Infant mortality, childhood nutrition, and ischaemic heart disease in England and Wales. Lancet 1986;i:1077-81.

2 Barker DJP, Osmond C, Golding J, Kuh D, Wadsworth MEJ. Growth in utero, lood pressure in childhood and adult life, and mortality from cardiovascular disease. Br Med f 1989;298:564-7.

3 Hasle $\mathrm{H}$, Jeune B. Childhood conditions and disability pension [English Abstract]. Ugeskr Laeger 1989;151:1926-8.

4 Williams DRR, Roberts SJ, Davies TW. Deaths from ischaemic heart disease and infant mortality in England and Wales. I Epidemiol Community Health 1979;33:199-202.

5 Pocock SJ, Shaper AG, Cook DG, Phillips AN, Walker M. Social class differences in ischaemic heart disease in British men. Lancet 1987;ii:197-201.

Accepted 29 November 1989)

\section{Intravenous thrombolysis for suspected myocardial infarction: a cautionary note}

\author{
Nicholas P Curzen, Bernard Clarke, \\ Huon H Gray
}

\section{Wessex Regional}

Cardiothoracic Unit,

Southampton General

Hospital, Southampton

SO9 4XY

Nicholas P Curzen, BM, senior house officer

Bernard Clarke, MD, senior registrar

Huon H Gray, MD, consultant cardiologist

Correspondence to: $\mathrm{Dr}$ Gray.

$\operatorname{Br} \operatorname{Med} \mathcal{f} 1990 ; 300: 513$

Use of thrombolytic agents to treat acute myocardial infarction reduces mortality by $10-30 \%,,^{1-1}$ and an increasing number of patients are now receiving such agents. We report two cases in which administration of streptokinase was probably inappropriate and had adverse consequences.

\section{Case reports}

Case 1-A previously fit 75 year old woman presented to hospital with a one hour history of anterior chest pain radiating through to her back. Although an electrocardiogram was normal, acute myocardial infarction was diagnosed clinically and intravenous streptokinase ( 1.5 million units over one hour) given. Eighteen hours later she developed further chest pain, which radiated to her legs, and an early diastolic murmur. A chest radiograph suggested a widened mediastinum, and she was transferred to the regional cardiothoracic unit with a diagnosis of aortic dissection. Aortography showed a type A dissection, but she died during an emergency operation. A postmortem examination did not show any appreciable disease of the coronary arteries.

Case 2-A previously fit 64 year old woman was admitted to her district hospital after the sudden onset of central chest pain several hours earlier. Electrocardiography showed inferior $\mathrm{T}$ wave inversion, and acute myocardial infarction was diagnosed. Intravenous streptokinase was given $(1.5$ million units over one hour), but three hours later she became hypotensive and collapsed. Echocardiography showed a pericardial effusion, and she was transferred to the regional cardiothoracic unit. On arrival she was hypotensive and could not be roused. Initially an aortogram was thought to be normal, and coronary arteriography was therefore undertaken; the results of this were normal. Subsequent analysis of the cineangiogram showed subtle changes consistent with type A disssection, and after resuscitation she was referred for urgent surgery, which confirmed the diagnosis. She was well four months later.

\section{Comment}

The reductions in infarct size and mortality from cardiovascular causes are greater the earlier thrombolytic agents are administered. As changes evident on electrocardiography may take time to develop some hospitals require only clinical criteria of infarction before thrombolytic agents are given. Most of the large trials of thrombolytic agents required electrocardiographic evidence of infarction before the agents were given, but two did not. ${ }^{34}$ In one of these, the AngloScandinavian study of early thrombolysis (ASSET), subset analysis showed that thrombolytic agents did not result in any significant reduction in mortality in patients with normal electrocardiograms.

Contraindications to the use of thrombolytic agents are well documented, but most trials do not report on patients whose condition was misdiagnosed and who received thrombolytic agents inappropriately. In the trials that required changes evident on electrocardiography $^{12}$ it is possible that there were no such cases or that they were unrecognised. In the Anglo-Scandinavian trial, however, eight patients were subsequently shown to have aortic dissection, of whom five died. Although dissection might conceivably have resulted from thrombolytic treatment, more probably the initial diagnosis was incorrect. As myocardial infarction may itself complicate type A aortic dissection, thrombolytic agents will inevitably be given to a few patients with dissection, even if electrocardiographic evidence of infarction is required before the drugs are administered.

The benefit offered by thrombolytic agents to the many patients with acute myocardial infarction is obvious. Our experience suggests that in the enthusiasm for using these agents some patients will be treated inappropriately and that such treatment may be life threatening. This raises the question of whether greater emphasis should be placed on the presence of electrocardiographic changes. If all general practitioners are to own an electrocardiograph, as recently recommended, 5 and are to be encouraged to start thrombolysis then guidelines on the relevance of electrocardiographic changes will need to be clearly stated.

1 Gruppo Italiano per lo Studio della Streptochinasi nell Infarto Miocardico (GISSI). Effectiveness of intravenous thrombolytic treatment in acu myocardial infarction. Lancet 1986;i:397-402.

2 Intravenous Streptokinase in Acute Myocardial Infarction Study Group. A prospective trial of intravenous streptokinase in acute myocardial infarction (ISAM): mortality, morbidity, and infarct size at 21 days. $N$ Engl $f$ Med 1986;314:1465-71

3 Wilcox RG, Olsson CG, Skene AM, van der Lippe G, Jenson G, Hampton JR. Trial of tissue plasminogen activator for mortality reduction in acute Tha myocardial infarction: Anglo-Scan

4 ISIS-2 (Second International Study of Infarct Survival) Collaborative Group. Randomised trial of intravenous streptokinase, oral aspirin, both or neither among 17,187 cases of acute myocardial infarction (ISIS-2). Lancet 1988;ii: among

5 Davies A. Electrocardiographs in general practice. $\mathrm{Br}$ Med $\mathcal{F}$ 1989;299:408-9.

(Accepted 10 November 1989) 